\begin{tabular}{|l|l|l||}
\hline \multicolumn{2}{|c|}{ PublisherInfo } \\
\hline \hline PublisherName & $:$ & BioMed Central \\
\hline \hline PublisherLocation & $:$ & London \\
\hline \hline PublisherImprintName & $:$ & BioMed Central \\
\hline \hline
\end{tabular}

\title{
Microdissection and microarrays
}

\begin{tabular}{|l|l|l||}
\hline \multicolumn{2}{|c|}{ ArticleInfo } \\
\hline \hline ArticleID & $:$ & 3744 \\
\hline \hline ArticleDOI & $:$ & $10.1186 /$ bcr-2000-66707 \\
\hline \hline ArticleCitationID & $:$ & 66707 \\
\hline \hline ArticleSequenceNumber & $:$ & 16 \\
\hline \hline ArticleCategory & $:$ & Paper Report \\
\hline ArticleFirstPage & $:$ & 1 \\
\hline \hline ArticleLastPage & $:$ & 4 \\
\hline \hline & & RegistrationDate : 2000-1-12 \\
\hline ArticleHistory & $:$ & OnlineDate \\
\hline \hline ArticleCopyright & $:$ & Current Science Ltd2000-1-12 \\
\hline \hline ArticleGrants & $:$ & \\
\hline \hline ArticleContext & $:$ & 1305833 \\
\hline \hline
\end{tabular}




\section{Keywords}

cDNA microarray, laser capture microdissection

\section{Introduction}

The study of gene expression within in vivo systems has previously been hampered by an inability to isolate the cells of interest from a complex tissue. However, this problem has been overcome by laser capture microdissection (LCM) techniques. At the same time, high throughput genetic analysis has become available in the form of cDNA microarrays. This study utilises both techniques to demonstrate the ability to examine expression of over 8000 genes from three distinct morphological stages of human breast cancer progression.

\section{Aims}

To analyse gene expression profiles of purified populations of human normal breast epithelial cells, malignant invasive breast carcinoma cells and malignant metastatic breast carcinoma cells (from an axillary lymph node).

\section{Comments}

This is an important step in the move towards the study of large gene-expression profiles from histologically characterised cells derived from human tumour specimens. Nevertheless, there are still obvious technical limitations exemplified by the number of cells required and the number of genes studied.

\section{Methods}


All tissue was obtained from a modified radical mastectomy specimen from a single patient, frozen, sectioned and stained prior to collection of specific cell types by LCM using Arcturus Pixcell LCM systems. Approximately 50,000 cells of each type were obtained at $>98 \%$ homogeneity.

RNA was isolated by guanidine isothiocyanate extraction, and used for microarray analysis (radiolabelled as cDNA probe on GeneFilter arrays - CBGF and GF211) and quantitative RT-PCR (Taqman). No amplification of RNA or cDNA was performed prior to probe labelling.

Immunoperoxidase staining was used to confirm some expression data.

\section{Results}

Less than $0.15 \%$ variability in gene expression patterns was demonstrated for duplicate filters.

Of 8084 cDNAs on the two microarray filters, 90 were found to be differentially expressed by twofold or more between normal epithelial cells and invasive cells, 112 between normal and metastatic cells and 29 between invasive and metastatic carcinoma cells. The number of differentially expressed genes was about three times greater on the tissue specific microarray (CBGF) than on GF211. The range of differential expression was between -40-fold and eightfold. A partial list of these genes is given, highlighting some that have previously been associated with breast cancer.

Expression of five genes was confirmed by RT-PCR and one by immunostaining.

\section{Discussion}

The feasability of screening in vivo subpopulations of cells from multiple stages of breast cancer progression, for expression of thousands of genes in parallel, has been demonstrated. In contrast to previous studies: cell populations were relatively pure due to microdissection; no amplification was used, maintaining representation; and, cells studied were both spatially and temporally distinct.

\section{References}


1. Sgroi DC, Teng S, Robinson G, LeVangie R, Hudson JR Jr, Elkahloun AG: In vivogene expression profile analysis of human breast cancer progression. Cancer Res. 2000, 59: 5656-5661. 